\title{
First record of Octopus vulgaris (Cuvier, 1797) (Octopodidae) in the Iraqi coastal waters, NW Arabian Gulf
}

\author{
Anwar M.J. Al-Maliky \\ Biology Department, College of Education for Pure Science, University of Basrah, Iraq \\ Khaled Kh. Al-Khafaji* \\ Marine Biology Department, Marine Science Centre, University of Basrah, Iraq \\ Tariq H. Al-Maliky \\ Marine Biology Department, Marine Science Centre, University of Basrah, Iraq
}

*Corresponding author. Email: khaled.saleh@uobasrah.edu.iq

\section{Article Info}

https://doi.org/10.31018/

jans.v13i3.2815

Received: July 8, 2021

Revised: September 3, 2021

Accepted: September 7, 2021

\section{How to Cite}

Al-Maliky, A.M.J. et al. (2021). First record of Octopus vulgaris (Cuvier, 1797) (Octopodidae) in the Iraqi coastal waters, NW Arabian Gulf. Journal of Applied and Natural Science, 13(3), 1048 - 1051. https://doi.org/10.31018/jans.v13i3.2815

\begin{abstract}
The present study identifies one species of the genus Octopus in the order: Octopoda (Cephalopoda: Mollusca), recorded for the first time in the Iraqi coastal waters and Arabian-Persian Gulf. The study extended from January 2019 to December of the same year. The Octopus specimens were seasonally obtained from the fishing trawlers operating in the Iraqi coastal waters in the South of Al- Fao District, Basrah- Iraq, NW Arabian Gulf. The Octopus was identified as O. vulgaris in Iraqi coastal waters depending on morphological features. The habitats of living specimens are briefly described. Some observations were reported on the occurrence of this species and the measurement of some environmental factors. The species was identified up to species level using standard literature. This species looks similar morphologically to the species which is already identified from the other areas around the world. The present study records significant expansion in the distribution range of this species.
\end{abstract}

Keywords: First record, Cephalopoda, Octopodidae, Octopus vulgaris

\section{INTRODUCTON}

Octopuses are marine benthic animals found to live from the sea coast down to $1000 \mathrm{~m}$ depth and they have been exploited for more than 2000 years as many as 200 species of Octopodidae occurrence in the world oceans (Worms, 1983). Order Octopoda includes two suborders, eleven families, about forty genera, and approximately two hundred species (Nesis, 1987). because to the scarcity of hard parts or other morphological characters and the high variability of their morphometric. The classification relies largely on the morphological characteristics of specimens making it difficult to identify the species, particularly in their preserved state. This poor resolution is caused not identified accurately for this species in local cephalopod fauna (Voss, 1967; Roeleveld, 1975).

The Arabian-Persian Gulf and Oman Sea constitute one of the most important marine ecosystems and have many economically important aquatic species, including several cephalopods. Cephalopods in general and Octopods, in particular, are the least studied in the Arabi- an Gulf waters (Valinassab, 1993). Octopuses are considered a delicacy in many countries. The most important fisheries and markets as a seafood in many countries are located in Asia (particularly Japan) and in the Mediterranean countries. Earlier Octopus was considered as a non-conventional resource and fishermen discarded it because of poor demand, but due to the increasing export market, even low-value octopods are now exploited (Sundaram and Sarang, 2011).

The common Octopus, O. vulgaris, was thought to be a cosmopolitan species, first described from the Mediterranean Sea and the Eastern North Atlantic and later reported in the subtropical and temperate East and West Atlantic Ocean, the Indian Ocean and West Pacific Ocean (Roper et al., 1984; Guerra et al., 2010; Norman et al., 2014). It is a largely exploited cephalopod species and this species is most important in economic aspect at the Mediterranean Sea and the Atlantic Ocean, and the coasts of Africa, Brazil, Japan and India, where its taxonomic identity is still debated (Guerra et al., 2010; De Luca et al. 2016; Melis et al., 2018; (Sundaram et al., 2019; Van Nieuwenhove et al., 2019 


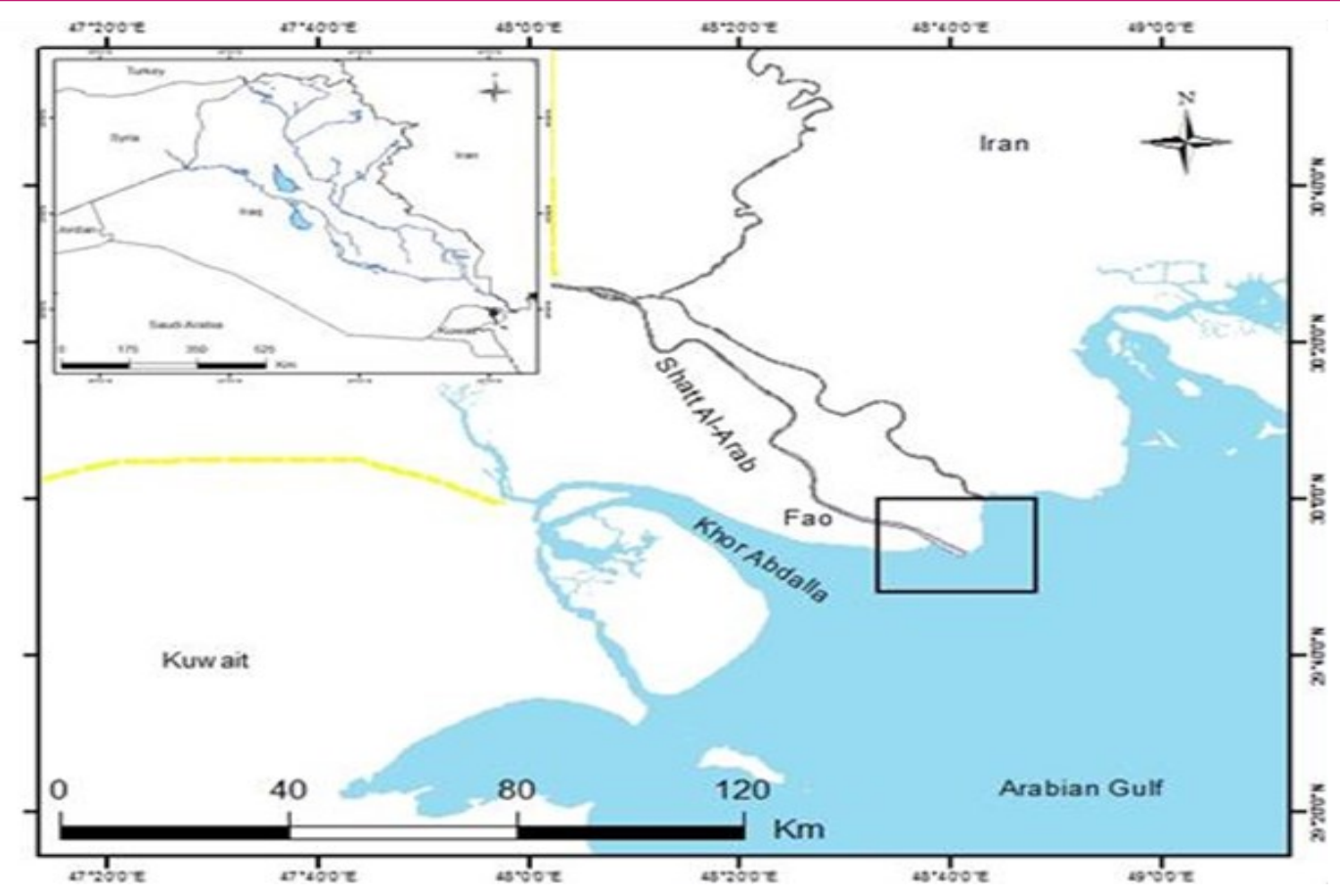

Fig. 1. Map showing sampling site in the Iraqi coast waters at south Al- Fao District, Iraq, NW Arabian Gulf.

Riad, 2020; Riad, 2021). The main objective of this study was to identify the occurrence of $O$. vulgaris from the Arabian Gulf by using morphological characters.

\section{MATERIALS AND METHODS}

The Specimens of Octopus were seasonally obtained from commercial fishing trawlers operating during the period from January to December 2019 from the Iraqi coast waters in south Al- Fao District, Iraq, NW Arabian Gulf (Fig. 1.). within the project of an environmental survey of Iraqi coastal waters by the Marine Biology Department of the Marine Science Center (MSC)- University of Basrah- Basrah province- Iraq. The depth was ranged from $5-20 \mathrm{~m}$. The specimens of the Octopus were brought to the laboratory and were placed in a plastic container with labels and preserved by $70-80 \%$ alcohol. and specimens of this species identification based on the morphological characters as described in (Roper et al., (1984); Silas et al., (1985); Jereb et al., (2014) and Amor et al., (2017). Further biological analysis was also carried out: total length $(T L)$ was measured using digital ruler.

The specimens were cleaned, photographed, preserved, and deposited in the Marine Biology Dep. Marine Science Centre (MSC), University of Basrah, Iraq.

\section{RESULTS AND DISCUSSTION}

The specimens of Octopus were identified as Octopus vulgaris on the basis of it morphological characters.

\section{Synonymy:}

Phylum: Mollusca.

Class: Cephalopoda (Clark, 1966).

Order: Octopoda (Leach, 1818).

Family: Octopodidae (Orbigny, 1839).

Octopus vulgaris Cuvier, 1797. (Fgures 2, 3).

The largest specimens had a total length of $91.5 \mathrm{~cm}$ for male and $82.6 \mathrm{~cm}$ for female.

\section{Description}

The body of $O$. vulgaris was oval and small compared with the head and arms, covered with flattened tubercles (Fig. 2). The head was large, with prominent eyes; three cirri were placed over each eye. The arms were thick and about equal in length; on their inner surface were seen the suckers arranged in double rows (Fig. 3 ), the bases of the arms were strongly webbed together. The dorsal pair of arms were shorter than the other arms and the length of the arms were about three times the body length.

The morphology of $O$. vulgaris in the present study agrees with the literature, except for the following additional characters; three cirri over each eye; this character was only stated by Forbes and Hanley (1852). The largest specimen in the current study had a total length of $91.5 \mathrm{~cm}$. for male and $82.6 \mathrm{~cm}$ for female. Fischer (1973) gave a maximum total body length 90 to 110 $\mathrm{cm}$. Roper et al. (1984) reported much larger sizes, total body length $130 \mathrm{~cm}$. for male and $120 \mathrm{~cm}$.

\section{World distribution}

West Mediterranean Sea, including Adriatic Sea (Roper et al., 1984) Turkish waters (Catagan and Kocatas, 


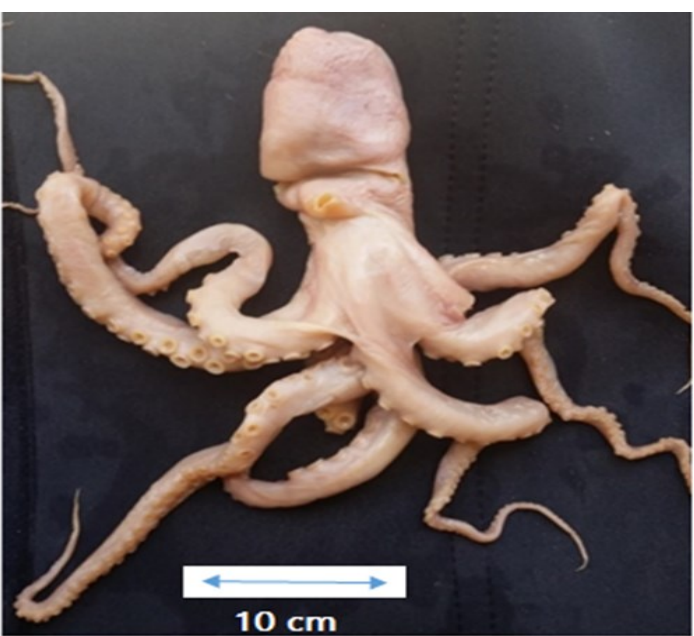

Fig. 2. Specimen of O. vulgaris collected from the South of Al-Fao city, Basrah- Iraqi, NW Arabian Gulf.

1990), occurs along the countries bordering in the Atlantic Ocean, the Indian Ocean and Arabian Gulf (Roper et al., 1984; Nesis, 1987; Norman et al., 2014).

\section{Local name: Okhtaboot}

\section{Local distribution}

The specimens were collected off shore of Rass AlBisha zone in South of Al-Fao city, Basra- Iraq, NW Arabian Gulf, by commercial fish trawl.

\section{Habitat}

On muddy sandy gravelly bottoms and also dwelling in cavities. Depth range from 5 to $20 \mathrm{~m}$. (Roper et al., 1984).

O. vulgaris Cuvier, 1797 known as 'common Octopus,' is a benthic, neritic species occurring from the coastline to the outer edge of the continental shelf and is found in various habitats, such as rocks and coral reefs, and grass beds. Though this species is commonly observed throughout its distribution range, but there is no study on this species from Arabian Gulf waters. Morphological studies are limited with regard to Octopods species in the coastal waters of the Arabian Gulf, and they are focused on recording the occurrence of other species within the Cephalopods group (Khatami et al., 2017 a; b; Khatami et al., 2018).

The species has a higher growth rate at high water temperatures due to an increased food intake rate (Mangold and Boletzky, 1973).

O. vulgaris life cycle spans from 9 to 15 months (Hernandez-Lopez and Castro-Hernandez, 2001; Smale and Buchan, 1981), the $10-15 \%$ of which is represented by the planktonic phase at paralarval stage (Villanueva et al.,1996) and sexual maturity reached in a few months (Fadhlaoui-Zid et al., 2012). The species lives on substrate rocky areas at the subtidal up to $20 \mathrm{~m}$ depth. The species are found in the rocky subtidal zone

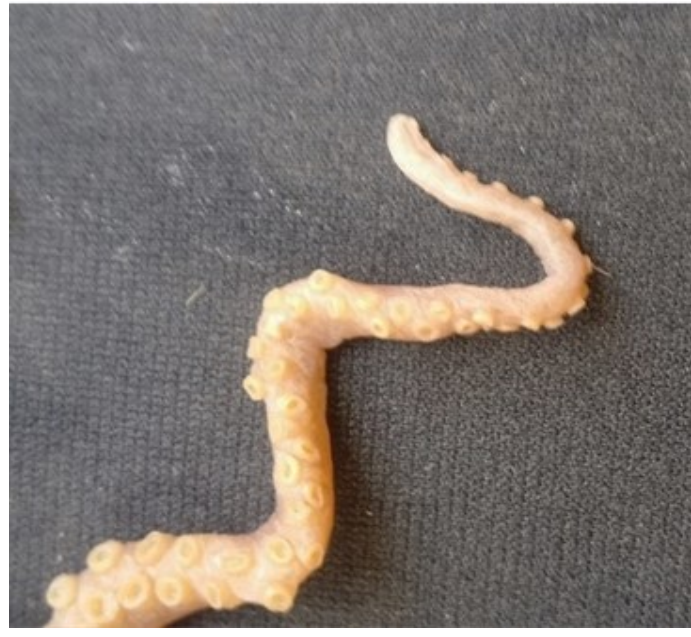

Fig. 3. Showing the suckers arranged in double rows in the $O$. vulgaris.

of Iraqi coastal waters. However, more samples of this species are needed to look at it carefully morphologically and genetically because of the few numbers of individuals collected and the long period of conservation and their effects on saved individuals.

\section{Conclusion}

The common Octopus, O. vulgaris Cuvier 1797 are sea animals of the order Octopoda belonging to the Cephalopoda class, Mollusca phylum. It is widely distributed in other areas around the world. Record of this O. vulgaris from Iraqi coast waters is an addition to the cephalopod fauna in Arabian Gulf. Its occurrence is reported for the first time from Iraqi coast waters and NW Arabian Gulf.

\section{ACKNOWLEDGEMENTS}

The study is a part of an ongoing project within the environmental survey of Iraqi coastal water. We thank Dr. Shaker Galib Ajil, the Head of the Department of Marine Biology of Marine Science Center- Basrah University-Basrah province- Iraq, for all the bits of help for the present study authors.

\section{Conflict of interest}

The authors declare that they have no conflict of interest.

\section{REFERENCES}

1. Amor, M.D., Norman, M.D., Roura, A., Leite, T.S., Gleadall, I.G. \& Reid A. (2017). Morphological assessment of the Octopus vulgaris species complex evaluated in light of molecular-based phylogenetic inferences. Zool Scr., 46, 275-288. https://doi.org/10.1111/zsc.12207

2. De Luca, D., Catanese G., Procaccini G. \& Fiorito G. (2016). Octopus vulgaris (Cuvier, 1797) in the Mediterra- 
nean Sea: Genetic Diversity and Population Structure. PLOS ONE, 11(2), 1-19. doi: 10.1371/journal.pone.014 9496

3. Fadhlaoui-Zid, K., Knittweis, L., Aurelle, D., Nafkha, C., Ezzeddine, S. \& Fiorentino, F. (2012). Genetic structure of Octopus vulgaris (Cephalopoda, Octopodidae) in the central Mediterranean Sea inferred from the mitochondrial COIII gene. CR Biol.,335, 625-636. https://www.um.ed u.mt/library/oar/handle/123456789/25931

4. Fischer, E. (1973). FAO species identification sheets for fisheries purp, Mediterranean and Black Sea (Fishing area37). Rom FAO. Vol.2.

5. Forbes, E. \& Hanley, S. (1852). A history of the British Mollusca and their shells. London. 4, 207-243.

6. Guerra, A.', Roura, A.', Gonza'lez, A.', F, Pascual, S., Cherel, Y. \& Pe'rez-Losada, M. (2010). Morphological and genetic evidence that Octopus vulgaris Cuvier, 1797 inhabits Amsterdam and Saint Paul Islands (southern Indian Ocean). ICES J Mar Sci., 67, 1401-1407. https://doi.org/1 0.1093/icesjms/fsq040

7. Hernandez-Lopez, J.L. \& Castro-Hernandez, J.J. (2001). Age determined from the daily deposition of concentric rings on common Octopus (Octopus vulgaris) beaks. Fish Bull., 99,679-684.

8. Jereb, P., Roper, C.F.E., Norman, M.D. \& Julian, K.F. (2014). Cephalopods of the world, an annotated and illustrated catalogue of cephalopod species of known to date. FAO species catalogue for fishery purposes, Octopods and Vampire squids. No.4, Vol.3. $388 \mathrm{pp}$.

9. Katagan, T. \& Kocatas, A. (1990). Note preliminaire sur les cephalopods des Eaux Torques. Rapp. Comm. Int. Mer. Medit., 32, 1, 242.

10. Khatami, S., Valinassab, T. \& Kaymaram, F. (2017a). Morphometric variation and growth rate of Uroteuthis duvaucelii (Cephalopoda: Loliginidae) in the Persian Gulf and Oman Sea using gladius increments. Iranian Journal of Fisheries Sciences 16(2) 851 -857.

11. Khatami, S., Tavakoli-kolour, P., Valinassab, T. \& Farhadi, A. (2018). Molecular identification and phylogenetic relationships of Coleoidea (Mollusca: Cephalopoda) from the Persian Gulf and Oman Sea reveals a case of cryptic diversity. Molluscan Research, 38(2),77-85. DOI:10.10 80/13235818.2017.1381062

12. Khatami, S., Kolour, P.T., Valinassab T., Anderson, F.E. \& Farhadi, A. (2017b). Molecular identification and phylogenetic relationships of Coleoidea (Mollusca: Cephalopoda) from the Persian Gulf and Oman Sea reveals a case of cryptic diversity, Molluscan Research, 38 (2), 77-85. https://doi.org/10.1080/13235818.2017.1381062

13. Mangold K. \& Boletzky S. (1973). New Data on Reproductive Biology and Growth of Octopus vulgaris. Mar. Biol. 19, 7-12.

14. Melis, R., Vacca, L., Cuccu, D., Mereu, M., Cau, A., Follesa, M.C.\& Cannas, R. (2018). Genetic population structure and phylogeny of the common Octopus Octopus vulgaris Cuvier, 1797 in the Western Mediterranean Sea through nuclear and mitochondrial markers. Hydrobiologia, 807: 277-296. https://link.springer.co $\mathrm{m} /$ article/10.1007/s10750-017-3399-5

15. Nesis, K.N. (1987). Cephalopods of the world. Squid, cuttlefishes, octopuses, Neptune City, NJ: T.F.H. Publications Inc., Ltd, $351 \mathrm{pp}$.

16. Norman, M.D., Hochberg, F.G. \& Finn, J.K. (2014). Octopods and Vampire Squids. In: Jereb P, Roper CFE, Norman MD, Finn JK (Eds) Cephalopods of the World. An Annotated and Illustrated Catalogue of Cephalopod Species Known to Date. FAO Species Catalogue for Fishery Purposes. 3, 33-270.

17. Roeleveld, M.A. (1975). A revision of Massy's checklist of South African Cephalopoda. Ann. S. Afr. Mus., 66(11), 233-255.

18. Riad, R. (2021). Comparative taxonomical studies on the Egyptian Mediterranean octopuses (Octopoda: Cephalopoda). Egyptian Journal of Aquatic Biology \& Fisheries. (3), 39 - 61. www.ejabf.journals.ekb.eg

19. Riad, R. (2020). Monograph of the Egyptian Octopuses Order: Octopoda (Cephalopoda: Mollusca). Part III. Egyptian Journal of Aquatic Biology \& Fisheries, 24(6), 73 102. www.ejabf.journals.ekb.eg

20. Roper, C.F.E., Sweeny, M.J. \& Nauen, C.E. (1984). Cephalopods of the world. FAO Fisheries Synopsis, 3(125), 5152

21. Silas, E. G., Rao, K. S. Sarvesan, R., Nair, K. P. \& Meiyappan. M.M. (1985). Identity of common species of cephalopods of India. In: Silas, E. G. (Ed.). Cephalopod bionomics, fisheries and resources of the Exclusive Economic Zone of India. Bull. Cent. Mar. Fis. Res. Inst., 37, 1337.

22. Smale M.J. (1981). Buchan PR. Biology of Octopus vulgaris off the east coast of South Africa. Mar Biol., 65, 1-12.

23. Sundaram, S., Mane, S. \& Bagade, D. (2019). Species diversity and basic biology of Octopus from Maharashtra waters, northwest coast of India, Int. J. of. Life Science, 7 (2), 212-220.

24. Sundaram, S. \& Sarang, J.D. (2011). Occurrence of Octopus vulgaris Cuvier, 1797 at Mumbai, Maharashtra. Marine Fisheries Information Service (210). pp. 16-17.

25. Valinassab, T. (1993). Identification of Cephalopoda in the Oman Sea. Iranian Fisheries Research Organization. Final Report of Research Project, 67.

26. Van Nieuwenhove, A.H.M., Ratsimbazafy, H.A. \& Kochzius, M. (2019). Cryptic diversity and limited connectivity in octopuses: Recommendations for fisheries management. PLoS ONE, 14(5),1-20. https://doi.org/ 10.1371/journ al.pone. 0214748

27. Villanueva, R., Nozais, C. \& Boletzky, S.V. (1996). Swimming behaviour and food searching in planktonic Octopus vulgaris Cuvier from hatching to settlement. J. Exp. Mar. Biol. Ecol., 208, 169-184.

28. Worms, J. (1983). World fisheries for cephalopods: A synoptic overview. In: J. E. Caddy (Ed.), Advances in Assessment of world cephalopod resources, FAO Fish. Tech. Pap., (231), 1-20.

29. Voss, G. L. (1967). Some bathypelagic cephalopods from South African waters. Annals of the South African Museum, 50 (5), 61-88. 